\title{
Facial Duplication: CASE, REVIEW, AND EMBRYOGENESIS
}

\author{
MASON BARR, JR. \\ Teratology Unit, Department of Pediatrics, University of Michigan, Ann \\ Arbor, Michigan 48109
}

\begin{abstract}
The craniofacial anatomy of an infant with facial duplication is described. There were four eyes, two noses, two maxillae, and one mandible. Anterior to the single pituitary the brain was duplicated and there was bilateral arhinencephaly. Portions of the brain were extruded into a large frontal encephalocele. Cases of symmetrical facial duplication reported in the literature range from two complete faces on a single head (diprosopus) to simple nasal duplication. The variety of patterns of duplication suggests that the doubling of facial components arises in several different ways: Forking of the notochord, duplication of the prosencephalon, duplication of the olfactory placodes, and duplication of maxillary and/or mandibular growth centers around the margins of the stomatodeal plate. Among reported cases, the female:male ratio is $2: 1$.
\end{abstract}

Duplication of the face, in whole or in part, on a single head is a very rare malformation that stimulates the embryologist to speculate on the mechanics of origin of not only the duplicated portions but also the normal portions of the same face. Those cases of facial duplication that have been reported in the literature seem, at least on external appearance, to constitute a spectrum extending from simple nasal duplication to complete separation of two faces on a single head (diprosopus). I have recently studied a case of facial duplication and would like to report the findings and to review and comment on the literature on the subject.

\section{CASE REPORT}

A female infant was born at 37 weeks of gestation to a 15-year-old black primigravida whose pregnancy was complicated by gestational diabetes mellitus, hypertension, and obesity. The birth weight was $2.6 \mathrm{~kg}$ and the Apgar scores were 5 and 6 and 1 and 5 minutes respectively. Severe craniofacial anomalies were noted and after assessment and consultation it was deemed that corrective and palliative therapy would be fruitless. Therefore, no efforts were made to sustain life and the baby died at 60 hours of age.

The midregion of the face was dominated by a large $(20 \times 25 \times 23 \mathrm{~mm})$ encephalocele covered by a thin investment of meninges (Fig. 1). On either side of the encephalocele was a completely formed nose, each with two nares, an intact nasal septum, and well-formed nasal cavities. Two well-formed eyes were positioned on the frontolateral aspects of the head; the distance between their inner canthi was 67 $\mathrm{mm}$. Two empty eye sockets were located in the interfacial region, immediately above the mouth and overlapped by the encephalocele. The right-medial socket was small and shallow and it contained a tiny, dyssplastic globe (Fig. 3). The left medial socket was better formed and empty. Beneath the upper lid of this socket there was a tract of loose areolar tissue extending upward toward the encephalocele. Attached to the left lateral margin of the encephalocele there was a $12 \cdot \mathrm{mm}$-diameter dysplastic ocular globe (Fig. 1).

There was a single oral opening. The mandible was broad but grossly and radiographically single and the normal cornplement of tooth buds was present. The lower lip was broad but otherwise normal. The tongue was broad, single, and with normal landmarks. The upper lip was formed by two laterally positioned lips connected by a featureless central portion. The left upper lip was intact with a normal philtrum. The right upper lip was cleft from the right medial naris through the right medial gingival ridge. The right premaxillary segment consisted of two fleshy lobes that protruded downward into the oral aperture (Fig. 3 ). Another shallow cleft extended from the naris to the right medial eye socket.

The maxillae were completely duplicated but fused to each other at their posterior medial borders. A normal complement of tooth buds

Received January 13, 1981; accepted January 19, 1981.

Dedicated with respect, admiration, and love to Josef Warkany. 


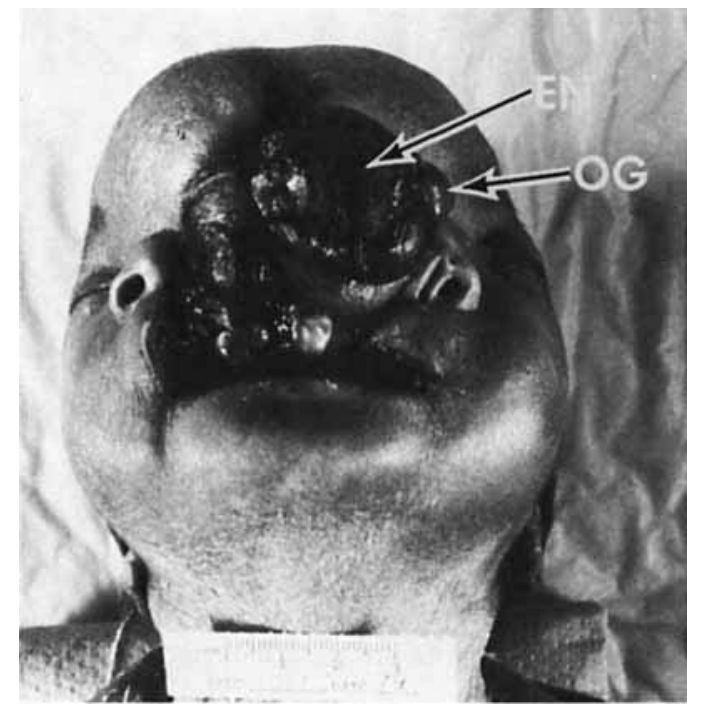

Fig. 1. Frontal view of infant with facial duplication EN, midfrontal encephalocele. OG, dysplastic ocular globe.

was present in the lateral halves of each maxilla, and each of the medial portions had incomplete sets of unerupted teeth. The secondary palates were intact and anteriorly the medial maxillary gingival margins were bridged across the midline by an expanse of featureless fibrocartilaginous tissue.

The course and branching of the external carotid arteries were unremarkable except that the descending (greater) palatine arteries were relatively increased in caliber. These vessels crossed the midline of each palate to supply, by many small branches, the interfacial region. There was also a continuation of these vessels upward into the cranial cavity just lateral to the point of fusion of the facial regions. After entering the skull cavity each vessel anastomosed with the ipsilateral anterior cerebral artery.

The skull was elongated in the anteroposterior dimension (Fig. 2) and was broad anteriorly. The ears were low set and posteriorally rotated. The occipital and parietal skull plates were unremarkable. On each side there were wellformed but laterally displaced frontal bones, the apices of which were separated by $35 \mathrm{~mm}$ across the midline of the vertex. In the anterior midline two short, thick frontal bones were fused to each other and offered minimal protection to the front of the head. These fused frontal bones were perforated by a $1-\mathrm{cm}$-diameter aper-

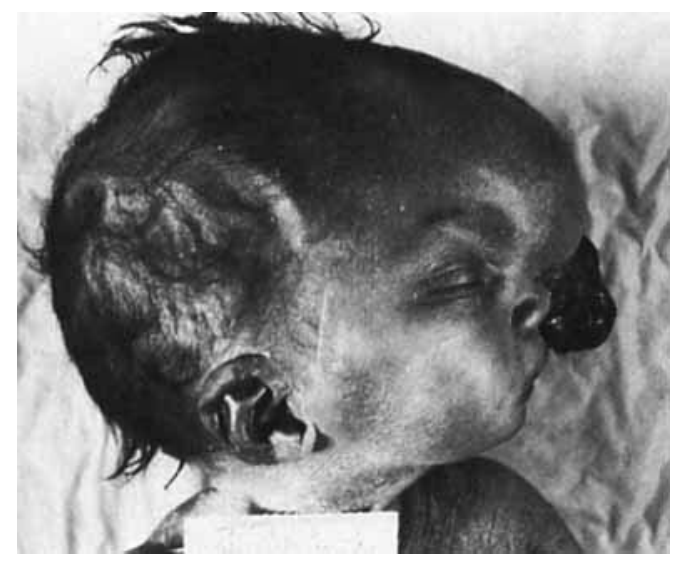

Fig. 2. Profile of infant with facial duplication, elongation of skull, and low-set ears.

ture that transmitted the stalk of the encephalocele in the anterior midline (Figs. 3,4).

The brain was dominated by two large cerebral hemispheres which on closer inspection were seen to be folded in upon themselves medially so that the medial portions were herniated into the ventricles. These dysplastic medial portions were continuous with the mass of neural tissue of the encephalocele. No trace of a longitudinal fissure could be discovered over the surface of either of the large hemispheric masses of cerebral tissue. No corpus callosum or other bridging structure existed between the hemispheres. Unfortunately, because of the prolonged period of antemortem hypoxia and acidosis the preservation of the brain was suboptimal and more detailed investigation of the internal anatomy was very difficult. The encephalocele consisted of disorganized neural tissue with many small and apparently isolated cavities lined by ependyma.

There were no olfactory bulbs or nerves, but two sets of optic nerves were identified (Fig. 4). Two small optic nerves arose from the stalk of the encephalocele and penetrated the interfacial region to course toward the empty eye sockets. Two optic nerves of normal size arose from the brain rostal to the hypophysis and each passed laterally through the lesser wing of the sphenoid bone to reach the laterally placed eyes. Optic chiasms as such could not be identified.

The pituitary and the sella turcica were normal in appearance and no hint of duplication could be discerned. Posterior to the pituitary all brain structures and cranial nerves ap- 


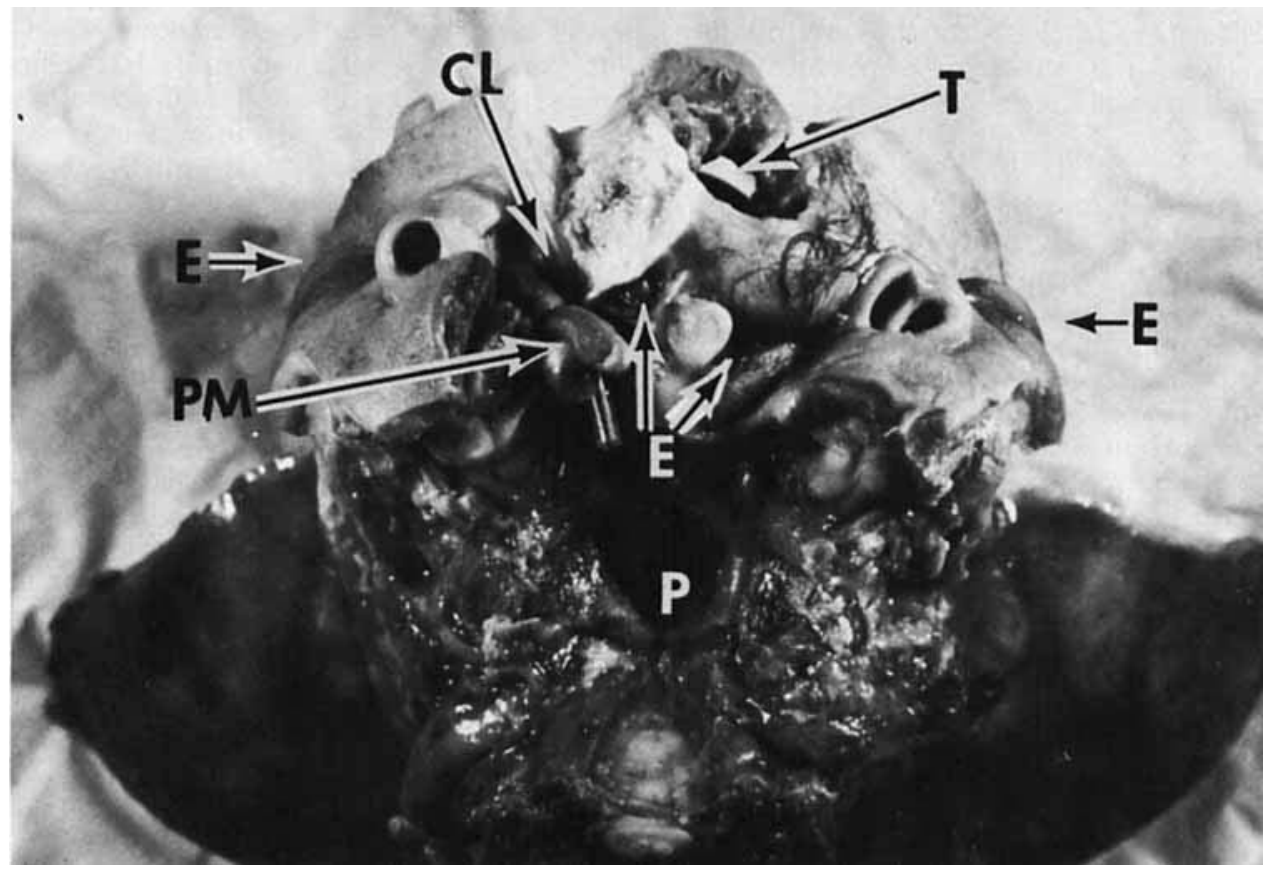

Fig. 3. Partially dissected face. T, aperture in the frontal bones through which the encephalocele passes. E, location of the four eyes. PM, premaxillary segment of the right face. CL, cleft lip of the right medial face. $P$, single pharynx with two uvulae.

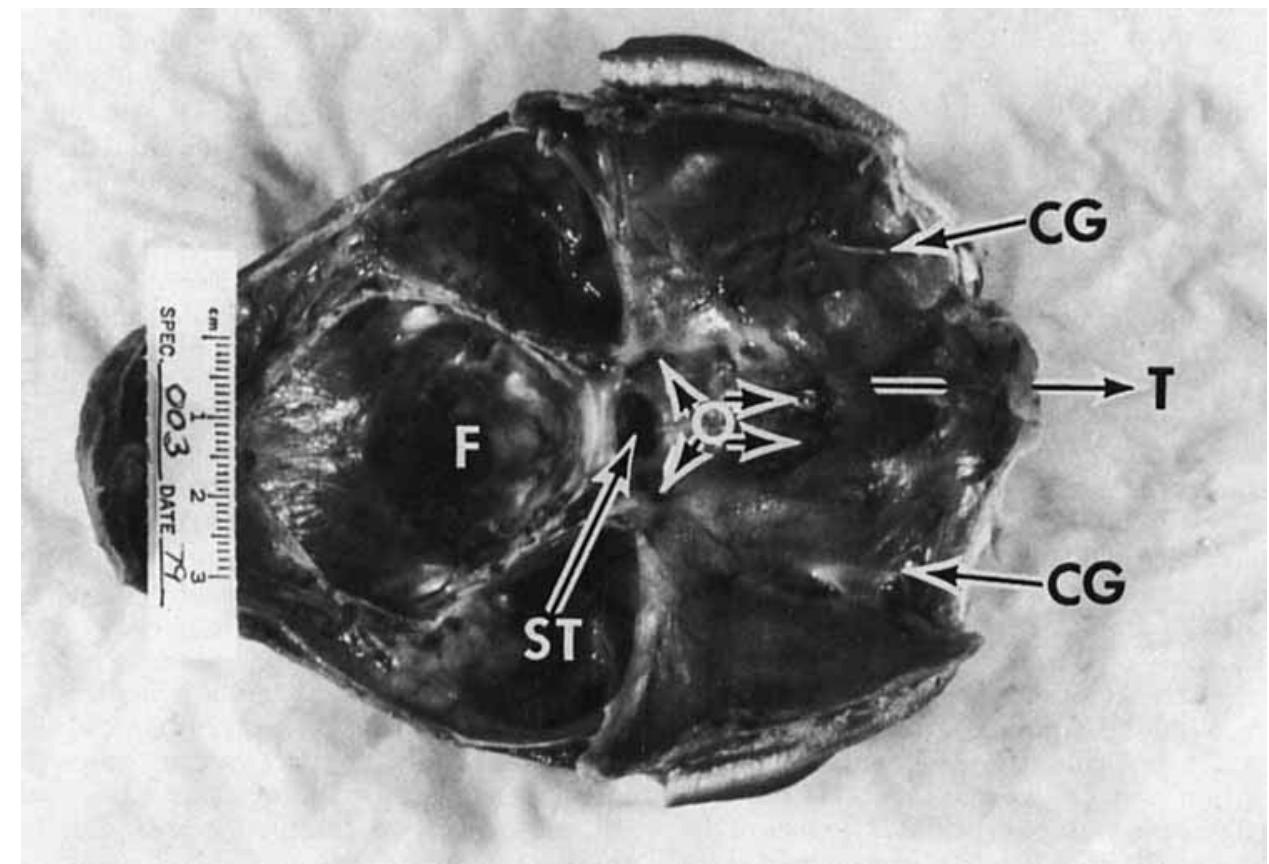

Fig. 4. Base of the cranial cavity. $T$, tract of the frontal encephalocele. CG, cristae galli, $O$, optic nerves. ST, selia turcica. $F$, foramen magnum. 
peared to be normally formed, without duplication. Elsewhere in the body the only malformation was a 3-mm-diameter membranous ventricular septal defect.

\section{DISCUSSION}

By external appearance symmetrical duplication of the face constitutes a spectrum ranging from isolated nasal duplication to complete doubling of all facial elements (diprosopus). The spectrum can be extended to include doubling of the entire head (dicephalus) and even to doubling of the body. Wilder ('08) proposed a spectrum of abnormalities that ranged from cyclopia to normal to dicephalus. This review and discussion will be limited to human cases involving duplication of facial elements on a single head. Also excluded from consideration are cases of unilateral accessory mouth and lateral replication of isolated segments of maxilla or mandible. Supernumerary nostrils also are not considered as they are located above rather than between the normal nostrils, do not form nasal septa, and appear to be due to accessory nasal pits (Erich, '79).

The literature on facial duplication is confused by the inclusion of cases of the medial cleft face syndrome and the amniotic band deformation complex. The median cleft face syndrome is manifested by a minimal-to-extreme separation of the two halves of the face, without duplication of facial structures (Cohen et al., '71). There is now general agreement that this condition follows failure of normal anterior extension of neural crest over the frontona. sal process (Johnson and Sulik, '79). Cases which were originally reported as facial duplication but which on review appear to be examples of the median cleft face syndrome are those of Lehmann-Nitsche ('01), Lasagna ('17), Wilkinson ('22), and Bumba and Lucksch ('27).

The amniotic band deformation complex may produce a secondary schism of the face and is, in such cases, associated with anencephaly, exencephaly, or encephalocele (Higgenbottom et al., 79). Despite the distortion of the face, there is no duplication of parts. Facial duplication cases that on review may represent cases of the amniotic band deformation complex are those of Windle (1889, Case No. 2) and Broder ('35). At one point in his discussion Broder alludes to mandibular and maxillary duplication but this is not evident in his case description.

With two possible exceptions, all cases of duplication of the eyes (i.e., the presence of three or four eyes) are accompanied by duplication of the nose as well (Table 1). The two exceptions are the cases reported by Linke and by Foerster. Foerster's (1865) case had doubling of the left frontal bone with two orbits but a single eyeball. The nose was single but no details of the osseous structure of the midfacial region are given. According to Rating ('33), the outward appearance of Linke's case was similar to Foerster's.

A case reported by Rating ('33) had a fusedcyclopic eye beneath a proboscis on the right side of the face, two normal laterally placed eyes, a normal left-sided nose, and a single mouth. Joly's (1857) case involved a more regular placement of the facial parts with the median eye placed between the well-formed but duplicated noses.

Complete facial duplication (diprosopus) has been reported a number of times (Table 1). Taruffi (1882) discusses duplication of the brain in diprosopus but since most of these cases were in fetuses with anencephaly, generalizations about duplication of the brain are impossible.

A lesser degree of facial duplication is represented by those instances where the median eye represents a fusion of the two sides but there is otherwise complete duplication of the nose and the upper and lower jaws (Table 1). The majority of these cases also were in anencephalic fetuses, but the cases of Hübner ('11) and Latteier and Anderson ('52) had intact calvaria. The latter authors were able to demonstrate four cerebral hemispheres and doubling of the cranial nerves I-VII. My case had four eyes, two noses, two maxillae, and a single mandible. The brain duplication involved only the prosencephalon derivatives anterior to the hypophysis. Somewhat similar cases were reported by Ledel (1687), Eschricht (1834), Wilde (1862), and Santi Sirena (1872) although these cases had a more normal disposition on the head of the facial components than did my case.

The association of eye duplication and nasal duplication would seem to make sense embryologically since duplication of eyes implies a duplication of the major portion of the prosencephalon. Such a duplication could then lead to the appearance of three or four optic vesicles and later from the rostral end of each prosencephalon a set of telencephalic vesicles, each with a rhinencephalon. Each pair of rhinencephalons would in turn induce the development of a pair of olfactory placodes, leading ultimately to two complete noses. The brain duplication in my case and that of Latteier and Anderson ('52) supports this contention. However, the importance of the rhinencephalon to 
TABLE 1. Case reports of facial duplication

\begin{tabular}{|c|c|c|c|c|}
\hline \multicolumn{4}{|c|}{ Number present } & \multirow[b]{2}{*}{ Authors** } \\
\hline Eye & Nose & Maxilla & Mandible & \\
\hline 4 & 2 & 2 & 2 & $\begin{array}{l}\text { Ammiano (1681), Aldrovandi (1642)., Pestalozzi (1722), } \\
\text { Bordenave (1761), Soemmering-2 (1791), Grillo (1813), Von } \\
\text { Lenhossek (1821), Geoffroy Saint-Hilaire (1836), Otto-3 } \\
\text { (1841), D'Alton-2 (1853), Depaul (1855), Serres (1860), Buhl } \\
\text { (1861), Macari (1865), Santi Sirena (1872), Sangalli (1875), } \\
\text { Lancereaux (1875), Brugisser (1881), Onof (1895), Gruber } \\
\text { and Eymer-2 ('27) }\end{array}$ \\
\hline 4 & 2 & 2 & 1 & $\begin{array}{l}\text { Ledel (1687), Eschricht (1834), Wilde (1862), Santi Sirena } \\
\text { (1872), this report. }\end{array}$ \\
\hline $3^{*}$ & 2 & 2 & 2 & $\begin{array}{l}\text { Chilian (1682), Scelhas (1864), Caccia (1721), Bongiovanni } \\
\text { (1789), Soemmering (1791), Cruveilhier (1849), Vrolik } \\
\text { (1849, 1856), Von Asch (ND), Meigs (1857), Gronau (1864), } \\
\text { Swayne (1867), Sangalli (1875), Macdonald (1875), Ahlfeld } \\
\text { (1880), Schwalbe ('07), Hübner ('11), Latteier and Anderson } \\
\text { ('52), Changaris and McGavran ('76) }\end{array}$ \\
\hline $3^{*}$ & 2 & 1 & 1 & Joly (1857), Rating (33) \\
\hline 3 & 1 & 1 & 1 & Foerster (1865), Linke (ND) \\
\hline 2 & 2 & 2 & 2 & Noodt (1839), Otto-2 (1841) \\
\hline 2 & 2 & 1 & 1 & $\begin{array}{l}\text { Borelli (1670), Bimar (1881), Windle (1889), Muecke and } \\
\text { Souttar ('23), Erich ('62), Ghosh et al. ('71), Mazzola-3 ('76) }\end{array}$ \\
\hline 2 & $11 / 2$ & 2 & 2 & Goulian and Conway ('64) \\
\hline 2 & 1 & 2 & 2 & $\begin{array}{l}\text { Buch (1866), Taruffi (1892), Feller-3 ('31), Clausnitzer ('56), } \\
\text { Morton ('57), Bacsich et al. ('64), Stiehm ('72) }\end{array}$ \\
\hline 2 & 1 & 2 & 1 & ? Broder ('35), Avery and Hayward ('69), Koblin ('70) \\
\hline 2 & 1 & 1 & 2 & ? Fontaine ('50) \\
\hline
\end{tabular}

* Median orbit with fusion of two ocular globes or, rarely, a single globe.

**Numbers in parentheses indicate the number of cases described in this category by the author(s) cited.

induction of the nasal placodes may be overstated since nasal development appears to proceed normally in the absence of discernible olfactory bulbs and nerves. Such is indicated in cases of simple arhinencephaly and in my case with two normal noses but absent olfactory bulbs and nerves.

If duplication of eyes inevitably involves duplication of the nose, the converse is not true. Nasal duplication may be isolated, or may be accompanied by duplication of the eyes (considered above) and/or duplication of the maxilla. Because of the often incomplete information given in the older case reports, an exact characterization of nasal duplication as either isolated or associated with maxillary duplication is difficult. Cases in which there were two eyes, two noses, and a single mouth were reported by Borelli (1670), Bimar (1881), Windle (1889), Muecke and Souttar ('23), Erich ('62), Ghosh et al. (71), and Mazzola (76, three cases). In the latter four reports the maxilla was not duplicated and they represent certain examples of isolated nasal duplication. In the unique case reported by Goulian and Conway ('64) there were three nostrils and three nasal cavities over a single mouth in which there was duplication of the mandible and maxilla.
Nasal duplication appears to arise in several ways. The status of the brain in cases of nasal or nasal plus maxillary duplication is generally unknown. The case reported by Bimar (1881) was noted to have a supplementary anterior cerebral lobe. As discussed before, prosencephalic duplication that includes eye duplication gives rise also to nasal duplication. It is probable that duplication of the prosencephalon rostral to the origin of the optic vesicles also leads to nasal duplication. However, there is at least one case report (Goulian and Conway, '64) in which there was nasal duplication in the absence of brain and basicranial duplication. The apparent neurological normality of the cases reported by Erich ('62) and by Ghosh et al. ('71) strongly suggests that only simple nasal duplication was present. Isolated nasal duplication could arise from bilateral replication of the olfactory placodes. In such cases, the medially placed nares and nasal chambers are smaller than the more normally formed lateral ones. How the upper lip is formed from the amalgamation of replicated maxillary and frontonasal processes is difficult to comprehend. Interestingly, the upper lips of these cases appear to be normal by description and photographs (e.g., Mazzola, '76). Broder ('35) stated that the up- 
per lip of Windle's $(1889$, no. 1) case had two ridges, suggesting the presence of two philtra; however, what Windle described was the presence of two phrenula of the upper lip. When nasal duplication has coexisted with cleft lip, the illustrations and descriptions in the literature seem to show that the cleft has involved only the medial naris, as it did in my case.

The last category of facial duplication concerns those cases with duplication of the maxilla, with or without mandibular duplication, but without nasal or optic duplication. Maxillary duplication appears to come in two varieties: Those cases with double pituitaries (Feller, '31, three cases; Clausnitzer, '56; Morton, '57; Bacsich et al., '64) and those with single pituitaries (Buch, 1866; Taruffi, 1892; Stiehm, '72). All of these cases were associated also with mandibular duplication. Maxillary duplication in the presence of a single mandible and a single pituitary has been reported by Avery and Hayward ('69) and by Koblin ('70). The presence of two pituitaries suggests the possibility that there was forking of the rostral end of the notochord (Giroud and Roux, '59) that led to doubling of the lower face. If forking of the rostral notochord is the antecedent of pituitary duplication, it is not the necessary antecedent of prosencephalic duplication. The cases reported by Clausnitzer ('56) and Bacsich et al. ('64) also had duplication of the cervical vertebrae but, other than duplication of the pituitaries, the brains were normal. Pituitary duplication may be isolated and is not, by itself, sufficient to result in maxillary duplication (Ahlfeld, 1880).

Just as it is difficult to comprehend the formation of the upper lip when there are two noses and a single maxilla, so it is when there are two maxillae and a single nose. Yet, several photographs of cases indicate that the lip has a normal philtrum in the central position.

Cases such as mine of maxillary duplication without mandibular duplication suggest that the maxillary arch is not simply a division of the first branchial arch. I would infer that the maxillary and mandibular arches arise from separate growth centers. If this is so, then in the absence of a forked notochord it may be supposed that maxillary/mandibular duplication could result from duplication of the growth centers around the margin of the stomatodeal plate. Separation of the stomatodeal plate into halves could give rise to duplication of both maxilla and mandible but would be expected to result also in two oral openings. The reported cases of maxillary/mandibular duplication, without nasal duplication, have had single oral openings.

Whether or not isolated mandibular duplication has been reported is arguable. Fontaine
('50) reported a case in which there was a toothcontaining bridge of bone extending from the symphysis mentis to the medial aspect of the right mandibular ramus. The mouth contained two tongues: A small right tongue and a normal left tongue that were fused posteriorly to form a common root. Theoretically, a replication of mandibular growth centers adjacent to the margin of the stomatodeal plate could give rise to two medially fused mandibles. What makes it uncertain whether or not Fontaine's case represents duplication is the apparent unilateral nature of the defect; it may be that this case resulted from a unilateral duplication of Meckel's cartilage.

Taruffi (1882) remarked on the preponderance of females among cases of facial duplication. An update of his tabulation shows that females outnumber males by $2: 1$. There is a high incidence of anencephaly with eye duplication and a preponderance of females among anencephalics. However, among cases of facial duplication with intact calvaria there is still an excess of females.

\section{ACKNOWLEDGMENTS}

The help of Samuel Hicks and Constance D'Amato in deciphering the morphology of the brain and of Andrew Poznanski in deciphering the roentgenograms is gratefully acknowledged. The references to prior case reports that are given as complete citations were found in the Taubman Medical Library of the University of Michigan. Case reports that were not examined directly carry the notation "cited by

." A number of these reports were quoted by two or more of the earlier reviews and the citation given in this paper is a compilation of reference information.

\section{LITERATURE CITED}

Ahlfeld, A. (1880) Die Missbildungen des Menschen. Leipzig: Grunow. Cited by Bacsich et al. ('64).

Aldrovandi, U. (1642) Monstrorum Historia Bononiae. Ch. III. p. 454. Cited by Taruffi (1882).

Ammiano, M. (1681) Rerum Gestarum. Parisis. Book 19, Ch. XII. Cited by Taruffi (1882).

Avery, J.K., and J.R. Hayward (1969) Duplication of oral structures with cleft palate. Cleft Palate J., 6:506-511.

Bacsich, P., W.D. Dennison, and A.M. MacDonald (1964) A rare case of duplicitas anterior. J. Anat., 98:292-293.

Bimar (1881) Sur une difformité rare de la tête et de l' encéphale. Gaz. Hebd. Sci. Med. Montpellier, 3:171, 194, 291.

Bongiovanni, Z. (1789) Descrizione d'una monstruosa bambina. Verona. Cited by Taruffi (1882).

Bordenave, T. (1761) Roux J. Med., 15:140. Cited by Taruffi (1882).

Borelli, P. (1670) Cited by Rating ('33).

Broder, S.B. (1935) An anencephalic monster with "rhinodymie" and other anomalies. Am. J. Pathol. 11:761-764.

Brugisser (1881) C.R. Soc. Helv., p. 100. Cited by Taruffi (1882).

Buch, J.A. (1866) De Monstro Humano Distomo. Inaug. 
Diss., Halle. Cited by Broder ('35).

Buhl, L. (1861) Doppelkopf (Diprosopus). In C. Hecker and L. Buhl (eds): Klinik der Geburtskunde. Leipzig: Verlag von Wilhelm, pp. 312-314.

Bumba, J., and F. Lucksch (1927) Ein fall von doggennase. Virchows Arch. [Pathol. Anat.], 264:554-562.

Caccia, G. (1721) In: Istoria della Generazione. Venice: Vallisneri. p. 453. Cited by Taruffi (1882).

Changaris, D.G., and M.H. McGavran (1976) Craniofacial duplication (diprosopus) in a twin. Arch. Pathol. Lab. Med., 100:392-394.

Chilian, B. (1682) Miscell. Naturae Curios., Dec. 2, Ann 1:356. Cited by Taruffi (1882).

Clausnitzer, K.H. (1956) Über eine diprosopie bei geschlos senen neurocranium. Zentrabl. Allg. Pathol. 95:329-336.

Cohen, M.M., Jr., H.O. Sedano, R.J. Gorlin, J.E. Jirásek (1971) Frontonasal dysplasia (median cleft face syndrome). Birth Defects, 7:117-119.

Cruveilhier, J. (1849) Traité d' Anatomie Pathologique, 1:360. Cited by Taruffi (1882).

D'Alton, E. (1853) De monstris, qui extremitatis superfluae suspensae sunt. Halis, p. 43. Cited by Taruffi (1882).

Depaul (1855) Monstre de la classe des monomphaliens. Paris: Bull. Acad. Med. 20:992-994.

Erich, J.B. (1962) Nasal duplication. Plast. Reconstr. Surg. 29:159-166.

Erich, J.B. (1979) Nose duplication. In D. Bergsma (ed) Birth Defects Compendium. 2nd ed. New York: A.R. Liss, pp. 783-784.

Eschricht (1834) Muller Arch. Physiol. Wissen. Med., 1:268. Cited by Taruffi (1882)

Feller, A. (1931) Über geringe grade von diprosopie. Z. Anat. Entwick., 94:181-205.

Foerster, A. (1865) Die Missbildungen des Menschen Systematisch Dargestellt. Jena: Druck und Verlag.

Fontaine, S.B. (1950) Congenital anomalies of the floor of the mouth and of the mandible. J. Oral Surg., 8:331-335.

Geoffroy Saint-Hilaire, I. (1836) Traité de Teratologie. Paris J.B. Ballière, Vol. 3, pp. 195-206.

Ghosh, P., K. Dada, S. Gupta, N. Jamwal, and R. Daljit (1971) Double nose. J. Laryngol. Otolaryngol. 85:963-969.

Giroud, A., and C. Roux (1959) Système chordal et morphogénèse de la tête chez l'embryon normal et chez les monstres doubles. Arch. Anat. Histol. Embryol. (Strosb.) 42:285-296.

Gouliari, D. Jr., and H. Conway (1964) A rare case of facial duplication. Plast. Reconstr. Surg., 33:66-72.

Grillo, A. (1813) Ragionamento in occasione d'un acranico. Naples, p. 26. Cited by Taruffi (1882)

Gronau, L. (1864) Uber ein diprosopus triophtalmus. Rostock. Cited by Taruffi (1882).

Gruber, G.B., and H. Eymer (1927) Beiträge zur kenntis der dicephalie. Beitr. Pathol. Anat., 77:240-276.

Higginbottom, M.C., K.L. Jones, B.D. Hall, and D.W. Smith (1979) The ammiotic band disruption complex. J. Pediatr., 95:544-549

Hübner, H. (1911) Die doppelbildungen des menschen und der tiere. Erg. Allg. Pathol. Anat., 15:650-796.

Johnston, M.C., and K.K. Sulik (1979) Some abnormal patterns of development in the craniofacial region. Birth Defects, 15:23-42.

Joly (1857). Cited by Rating (' 33 ).

Koblin, I. (1970) Zwischenkiefer verdoppelung mit normotoper und heterotoper zahnüberzahl sowie gaumenspalte. Dtsch. Zahn-Mund-Kieferheilk., 54:204-210.

Lancereaux, E. (1875) Traité d'Anatomie Pathologique, 1:70. Cited by Taruffi (1882).

Lasagna, F. (1917) Di un raro caso di naso doppio congenito. Arch. Ital. Otolaryngol. Rinol. Laryngol., 28:329-334.

Latteier, K.K., and R.T. Anderson (1952) Diprosopus. Med. Radiogr. Photogr., 28:22-24.

Ledel, S. (1687) Ephem. Naturae Curios. Dec. 2, Ann 6, p. 152 (Obs. 64). Cited by Taruffi (1882).
Lehmann-Nitsche, R. (1901) Ein seltener fall von angeborener medianer spaltung der oberen gesichshalfte. Virchows Arch. [Pathol. Anat.], 163:126-134.

Lesbre, F.X., and J. Jarricot (1910) Contribution à l'étude des monstres polygnathiens. J. A.nat. Physiol., 46:105-145. 46:105-145.

Linke (ND). Cited by Rating ('33).

Macari, F. (1865) Giorn. R. Acard. Med. Torino, Ser 2a, 52:501. Cited by Taruffi (1882).

MacDonald (1875) Description of a diprosopus triophthalmus monster. Edinb. Med. J., 20:702-708.

Mazzola, R.F. (1976) Congenital malformations in the frontonasal area. Clin. Plast. Surg., 3:573-609.

Meigs, C.D. (1857) Case of double foetus. Am. J. Med. Sci., 33:45-47.

Morton, W.R.M. (1957) Duplication of the pituitary and stomatodaeal structures in a 38 -week male infant. Arch. Dis. Child., 32:135-141.

Muecke, F.F., and H.S. Souttar (1923) Case of double nose Proc. R. Soc. Med. Sect. Laryngol., 17:8-9.

Noodt, G.W. (1839) De monstro quodam humano. Schoonhoviae. Cited by Taruffi (1882).

Onof, B. (1895) A case of double formation of the face with cranioschisis. Med. Rec., 48:401--404.

Otto, A. (1841) Monstrorum sexcentorum descriptio anatomica. Breslau. Cited by Foerster (1865).

Pestalozzi, G.G. (1722) In: Richa, C. Morborum Vulgarum Historia, Augustae Taurinorum, p. 165, 212. - Pestalozzi. Observations sur la physique, 14:122, Paris. Cited by Taruffi (1882).

Rating, B. (1933) Uber eine ungevöhnliche gesichtsmisbildung bei anencephalie. Virchow's Arch. [Pathol. Anat.], 288:223-242.

Sangalli, G. (1875) La Scienza e la Pratica. Pavia, p. 114. Cited by Taruffi (1882).

Santi Sirena (1872) Enciclopedia Med. Ital., Pt. 1, 2:595, 600. Cited by Taruffi (1882).

Cited by Taruffi (1882).

Scelhas, E.F. (1864) Ephem. Naturae Curios., Dec. 2, Ann 3:302. Cited by Taruffi (1882).

Schwalbe, E. (1907) Die Morphologie der Missbildungen der Menschen und der Tiere. Jena: G. Fischer, Vol. 2, pp. 283-301

Seres (1860) Mem. Acad. Sci. Paris; 25:866. Cited by Taruffi (1882).

Soemmering. S.T. (1791) Abbildungen und Beschribungen einiger Missgeburten. Mainz. Cited by Foerster (1865).

Stiehm, W.D. (1972) Facial duplication. Am. J. Roentg., 116:598-601

Swayne, J.G. (1867) Trans. Obstet. Soc. Lond., 8. Cited by Taruffi (1882)

Taruffi, C. (1882) Storia della Teratologia. Bologna: Regia Tipografia, Vol. 2, pp. 488-514.

Taruffi, C. (1892) Feto umano con due mandibole simmetriche. Acad. Sci. Inst. Bologna. Cited by Lesbre and Jarricot ('10)

Von Asch, L.B. (ND) Zeichnungen von Missgeburten der Moskauer Sammlung. Gottingen. Cited by Taruffi (1882).

Von Lenhossek (1821) Med. Jahrb. Oest. Staats, 6(3):134. Cited by Taruffi (1882).

Vrolik, V. (1849) Tabulae ad illustrandem embryogenesis hominis et mammalium tam naturalem quam abnormalem. Amsterdam. Cited by Foerster (1865).

Vrolik, V. (1856) Kanstatt Jahresbericht, 4:1, 11. Cited by Taruffi (1882)

Wilde, E.R. (1862) An essay upon the malformations and congenital diseases of the organs of sight. Dublin Q. J. Med. Sci., 33:71-75.

Wilder, H.H. (1908) The morphology of cosmobia. Am. J. Anat., 8:355-440.

Windle, B.C.A. (1889) Three cases of malformations connected with the face. Anat. Anz., 4:219-223.

Wilkinson (1922) A case of bifid nose. J. Laryngol., $37: 560-563$. 